\title{
People as the Roots (of the State): Democratic Elements in the Politics of Traditional Vietnamese Confucianism
}

\author{
Tai-Dong Nguyen', Manh-Tung Ho ${ }^{1,2}$ \\ 'Institute of Philosophy, Vietnam Academy of Social Sciences \\ ${ }^{2}$ Centre for Interdisciplinary Social Research, Phenikaa University
}

\begin{abstract}
In this paper, the concept of "people as the roots" (of the state) is explored through its myriad expressions in Vietnamese history: the emphasis of Vietnamese feudal rulers on fulfilling the people's will, loving the people, and ensuring peace for the people. From these historical examples, the authors argue that in the politics of Vietnamese traditional Confucianism, there has been the presence of democratic elements. Yet, they do not reflect a full-fledged democracy and should be seen only as signs of village democracy. This view holds an important implication for the process of democratization of modern Vietnamese society: while the concept of "people as the roots" is essential for a village democracy and is valuable for building a democracy, it does not necessarily mean a straightforward translation to a modern democracy. Here, the authors suggest that civil society will play an important role in making this transition smoother.
\end{abstract}

\section{Keywords}

Vietnamese Confucianism; people as the roots; politics, democracy; village democracy; grassroots democracy

\section{Introduction}

Debates on democracy within Confucianism, which often fall into the realm of Chinese studies, arose in the 20th century when the democratic system became more prevalent around the world. Given that Confucianism and democracy are elements of different cultures (Lee 1999), scholars have spent enormous efforts to analyze the nature of their relationship, whether that be the compatibility of Confucianism with Western democracy (Hu 1997), the interaction between Confucianism and democratic development in East

\footnotetext{
* Tai-Dong Nguyen, Institute of Philosophy, Vietnam Academy of Social Sciences, 59, Lang Ha St., Ba Dinh Dist., Hanoi 100000, Vietnam; ntaidong@yahoo.com; Manh-Tung Ho (corresponding author), Institute of Philosophy, Vietnam Academy of Social Sciences, Vietnam Academy of Social Sciences, 59, Lang Ha St., Ba Dinh Dist., Hanoi 100000, Vietnam; Centre for Interdisciplinary Social Research, Phenikaa University, Yen Nghia, Ha Dong, Hanoi 100803, Vietnam; tung.homanh@ phenikaa-uni.edu.vn.
} 
Tai-Dong Nguyen, Manh-Tung Ho, People as the Roots (of the State): Democratic Elements in the Politics of Traditional Vietnamese Confucianism

Asia during modernization (Lee 1999), or the foundation for Confucian democratic political thought (Ackerly 2005). Other studies even looked to reconcile socialism and Confucianism in China (Bell 2009) or proposed a different set of political possibilities in which democracy could grow out of Chinese Confucian roots (Weller 1999). These studies share in common an implicit understanding that the value of democracy is not something natural or intrinsic within the set of Confucian values. Kim (2017) made a different argument regarding this point, suggesting that both democracy and Confucianism share the dual aspects of being a political system and a way of life, and thus, can be consolidated as "pragmatic Confucian democracy." The term essentially means a continual negotiation between democratic practices and Confucian values and moral sentiments (Kim 2017). Another attempt to better grasp the topic is analyzing the old texts of Mou Zongsan (1909-1995) and Tang Junyi (1901-1978), arguably among the most productive Confucian philosophers of the 20th century, on the relationship between democracy and Confucianism (Fröhlich 2010).

This study approaches the topic in a slightly different manner - it examines an ancient Vietnamese concept that carries democratic meaning today to support the view that traditional Confucianism can indeed embrace certain elements of democracy. It adds to the literature by providing a unique perspective from Vietnam, which has such a close geographical and cultural proximity to China that sometimes the arbitrary adaptation and transformation of certain traditional Chinese values here is overlooked (Vuong et al. 2018, Vuong and Tran 2009). The topic deserves attention because since Vietnam transitioned to a market economy from a planned one in 1986, the fusion of socialist and capitalist ideas has brought about massive economic and political changes to the country (Vuong 2014; Vuong 2019). Several studies have looked at the development of grassroots or village democracy in Vietnam (Zingerli 2004, Duong 2004, Wells-Dang 2010), but none has examined the feudal rhetoric and its relevance today. Before delving into the thesis of this paper, the next section reviews some major debates in the literature.

\section{Filling the Gap}

While Confucianism, primarily known as a secular social theory, is complex and irreducible to simple definitions, there are different interpretations of its theory as well as numerous attempts at classifying types of Confucianism in the modern age. Dirlik (1995) noted on the proliferation of research into Confucianism, which has resulted in not just Chinese, Taiwanese, Japanese, and Singaporean Confucianisms but also a host of other types such as "social 
Confucianism," "folk Confucianism," or "mass Confucianism." There is also a distinction among "lively" Confucianism, imperial Confucianism, and critical Confucianism by Lin Anwu; an analysis of democracy in Confucianism from three perspectives of approach that is virtue, ritual-morality and equality by Sorhoon Tan; and Lee Ming-huei's suggestion of a "deep-level" Confucianism capable of influencing the mind of the Chinese subconsciously (Chen 2007). Among the notable terms is the distinction between imperial (or institutional) Confucianism and social Confucianism by the Hong Kong sociologist Ambrose Y. C. King. Here, imperial Confucianism is defined as "a complex and sophisticated combination of state ideology as well as a set of strategic institutions, including the literati, the examination system, and above, the imperial bureaucracy" while social Confucianism refers to "a set of Confucian beliefs and values accepted widely by the man in the street" (King 1996, 275). With this view, imperialist Confucianism or political Confucianism is not compatible with liberal democracies.

The American political scientist Samuel P. Huntington is one of the most wellknown scholars denying the view that Confucianism contains democratic values. Huntington viewed Confucianism as being antidemocratic, and Confucian democracy is a contradictory term (Huntington 1991b). Specifically, Huntington regarded the two concepts as being fundamentally contradictory because a democratic tradition of rights against the state is absent in Confucian societies due to an overemphasis on harmony, cooperation, order and respect (Huntington 1991a, 24). On this ground, Huntington predicted a "clash of civilizations" between a liberal democratic West and the antidemocratic tyrannical Confucianism. Along with this line of argument, many scholars have pointed out that Confucius overemphasizes responsibility for the loss of human rights, the ideal of loyalty that harms freedom, and the basic principle of Confucianism that is against equality. In short, Confucianism is not necessarily compatible with democracy (Nuyen 2000, 136-138, Hu 1997). The political scientist and China expert Lucian Pye also held that Confucian political culture is authoritarian and that it an obstacle to democratization in Asia (Tan 2010, 103). Pye and Huntington argued that the root of the problem is that the Confucian tradition does not develop a kind of political philosophy that supports liberal democracy like that of the West. The ideal to rule by a virtuous person rather than to rule by the law does not help individual rights. Placing the management of the country before that of the family leads to patriarchal behavior, easily slipping into authoritarian territory (Chang, Chu, and Tsai 2005, 8). 
Tai-Dong Nguyen, Manh-Tung Ho, People as the Roots (of the State): Democratic Elements in the Politics of Traditional Vietnamese Confucianism

The criticism that Confucianism is undemocratic is also held by many Chinese thinkers even very early on, from Lu Xun (1881-1936) to those who lived through the Cultural Revolution (1966-1976). Chen Duxiu, one of the leaders of the New Culture movement, said that Confucius' ideas and teachings belonged to the feudal era, thus its morality, norms, modes of living, and political institutions did not overcome the privileged status and privilege of a few rulers and nobles, nor did they bring about happiness for the majority of people. Many Chinese intellectuals at the time believed that the Chinese Confucian legacy hindered the modernization process, especially the democratization process (Tan 2010, 104).

However, other researchers hold that to assume the whole of Confucianism is autocratic could be erroneous. Depending on the classifications and approaches, scholars will have different attitudes when assessing the relationship between Confucianism and democracy. Francis Fukuyama divided Confucian thoughts into two categories: political Confucianism and Confucian personal ethics. In fact, Francis Fukuyama's classification is inherited from Tu Weiming (1984), as cited by Fukuyama (1995, 26). Political Confucianism emphasizes imperial and gentry power, which together define a ruling social hierarchy as the upper structure of society. Meanwhile, Confucian personal ethics stress family values and a system of personal ethics; this is the true essence of Confucian culture. At the same time, Francis Fukuyama also argued that Confucianism embraces the values of elitism, education, and tolerance, all of which are in harmony with, and even beneficial for modern liberal democracy (Chang, Chu, and Tsai 2005, 6).

Supplementing an understanding of the two terms requires an objective view of democracy, on which different interpretations sprout. Democracy is not just a political system in which a government is chosen in the narrow sense through popular elections but also carries a broader meaning of a driving force or a moral ideal and social ideal, as John Dewey argues (Tan 2010, 106-107). Democracy, in this sense, represents a whole and complete community, with its cause being the moral cause of the dignity and worth of the individual.

Building on this definition, Fukuyama argued against the viewpoints that democracy and Confucianism are incompatible. First, the traditional Confucian examination system was a meritocratic institution with potentially egalitarian implications. In their modern form, however, the examination systems are implemented in many Confucian societies as gateways into higher education systems and bureaucracies. Second, the Confucian emphasis on education underlines the individual need or pursuit of knowledge. Although an educated populace is seldom noted as a formal requirement of democracy, 
in practice a society's general level of education has been an important underpinning of democratic institutions. Without a high level of literacy, people cannot know about and therefore participate in democratic debates; moreover, as indicated above, education tends to make people wealthier and more concerned with noneconomic issues such as recognition and political participation. Finally, like most Asian ethical systems, Confucianism is relatively tolerant. In the past, Confucianism has coexisted with other religions, notably Buddhism and Christianity; it is arguably more tolerant than either Islam or Christianity (Fukuyama 1995, 25). According to Fukuyama, the Chinese ethicist and Confucian scholar Tu Weiming argues that the more important legacy of traditional Confucianism is not its political teaching, but rather the personal ethics that regulate attitudes toward family, work, education, and other elements of daily life (Fukuyama 1995, 26). The concept of democracy described by Fukuyama shows that Confucianism builds a well-ordered society from the bottom up rather than from the top down, stressing the moral obligations of family life as the basic building block of society. Consequently, the relationship between Confucianism and democracy is much more complex than the common perception.

On this view, Confucianism and democracy are two independent systems that coexist: Asian societies have the right to choose their own path. Their historical and cultural practices may allow their future decisions to differ from other societies. Even at a price of lacking in democracy, societies with a long legacy of Confucianism are unlikely to be better off eradicating its influence. It is noted that even Western scholars who argue that the values of Confucianism and liberal democracy have internal conflicts may still believe on their ability to coexist as "independent value systems" within the same society. The two concepts, therefore, are not contradictory (Tan 2010, 104, Kim 2017).

There also exists a third ground in which scholars find Confucianism to be neither democratic nor antidemocratic but instead a-democratic, which does not facilitate the democratization process (Hu 1997).

\section{"Democracy" in Vietnamese society}

The literature shows ongoing debates between the compatibility of Confucianism and democracy and the potential room Confucianism has for democratization. Much of the aforementioned debates center on the popular understanding of Confucianism in China or East Asia and of democracy in the West. This leaves a gap for smaller countries such as Vietnam, where the influence of both Confucianism and democracy is felt widely and differently 
Tai-Dong Nguyen, Manh-Tung Ho, People as the Roots (of the State): Democratic Elements in the Politics of Traditional Vietnamese Confucianism

(Vuong et al. 2018). Theoretically, this paper offers an unconventional understanding of democracy in the Confucian tradition through the concept of "people as the roots" (民本).

In addition, studies on the topic have also overlooked the texts of ancient rulers, who were influenced by Confucianism to uphold the mandate of Heaven, all the while striving for a harmonious balance between the governor and the governed. This study diverges from the common approach by examining the presence of democratic elements in ancient Vietnamese texts, particularly in the speeches and words left by its ancient rulers and court mandarins. Although historical records written by the rulers themselves at the time are subject to biases, the historical events that had unfolded, such as whether the rulers had built a prosperous dynasty and won or lost a war, are undeniable facts. These facts serve as the basis for this study to interpret the meanings behind the texts cited.

Similar to the root demos that means "common people," the word "democracy" in both Chinese and Vietnamese languages, respectively, 民主 and dân chủ, also denotes a literal meaning of the people ruling or leading. When discussing this concept, the Vietnamese philosopher Ho Si Quy (2015) noted that the application of dân chủ in both its simple (people as leaders) and complex meanings (power belonging to the majority) is still absent, even unfamiliar, in Vietnamese society. However, there does exist the popular notion of "village democracy" in Vietnam, in which villagers or farmers take ownership of their farmland and agricultural lifestyle while practicing a kind of "Confucian democracy, Buddhist equality, and Taoist freedom" (Ho 2015). This interpretation is also held by the contemporary Vietnamese historian Phan Huy Le, such that even during the feudal period, Vietnamese farmers' closest ideals to democracy stopped at their demand for societal fairness and equality, for a country to be ruled by a bright and benevolent king (Phan 1998, Ho 2015).

On the extant literature on grassroots or village democracy in Vietnam, to gauge whether there are indeed democratic elements within the Vietnamese system, Duong (2004) looked at the Marxist-Leninist principle of democratic centralism - which means the people and party members can discuss issues at all levels but the central authority represents the individuals collectively and gets to make the final decisions. Zingerli (2004) highlighted the constraints in the government's decree no. 29, which was issued in 2000, on theoretically increasing public participation in decision-making, monitoring, and supervision at the communal level. Wells-Dang (2010), however, expressed more optimism in his study, arguing that Vietnam might become a "rice-roots democracy" in practice even if its political regime stays unchanged. Larsen 
(2011) performed a discursive analysis of the construction of the ideal image of grassroots democracy by political professionals. The author found that the concept had served as a conceptual mediator between diverging interests related to rural development and different ideological positions surrounding the notion of democracy.

Within this background, this study introduces another interpretation of democracy in traditional Vietnamese society, as manifested in the concept of "people as the roots" - a literal translation of lấy dân làm gốc in Vietnamese. It is important to note that, although both the Confucian policy of people as the roots (of the state) or 民本 and liberal democrats pursue the ideals of community interest, they differ in many respects. First, despite their insistence on having the government operate for the benefit of the people, the two are different in the way to implement good governance: if liberal democracy requires appropriate procedures, Confucianism suggests that there should be a stable hand of the elites. Second, their views diverge on the legitimacy of government. In the tradition of freedom and democracy, a government has legitimacy mainly through a just election. However, according to the doctrine of the "people as the roots," in essence, the legitimacy of a government is determined by the nature and results of the policies that the government has made. Third, each philosophy emphasizes the role of public political participation. In a free democracy, such participation is the fundamental right guaranteed by the social contract between citizens and their government. In the doctrine of the "people as the roots," however, the political participation of civilians is limited to expressing their concerns with the authorities (Shi and Lu 2010). With this view, it is not easy to concede that Confucianism is democratic or antidemocratic. At least, what is made clear is, even if Confucianism and democracy have certain contradictory ideas, they can coexist in modern society, with some Confucian values able to propel East Asia toward modernization and democratization (King 1996).

\section{The Concept of "People as the Roots" in Traditional Vietnamese Confucianism}

In 1945, the monarchy was officially abolished in Vietnam, subsequently initiating the building of a democratic republic of Vietnam. However, even in the monarchy, democratic elements could still emerge and develop. Democratic ideals, norms, and values are not completely opposed or eliminated by the monarchy, because a monarchy or a republic refers to the form of government, while democracy or dictatorship is about a form of political governance. After all, whether the form of a country's government is a monarchy or a republic does not affirm whether it is truly a democracy. In traditional Vietnamese Confucian 96 
Tai-Dong Nguyen, Manh-Tung Ho, People as the Roots (of the State): Democratic Elements in the Politics of Traditional Vietnamese Confucianism

thought, this paper argues, the seed of democracy manifested most clearly through the concept of the "people as the roots." The expression carries the idea that the people's will is the same as the Heaven's will. In other words, the king and the mandarins are bound by this heavenly will to love the people, to make people believe in them, and to keep the people safe and peaceful.

\section{The Will of the People and Heaven}

Taking people as the roots is a fundamental political concept of Confucianism. In the Book of History, one of the five classics of ancient Chinese philosophy, there is a phrase: "People are the roots of the nation. If the roots are not firm, the nation will collapse” (“民惟邦本, 本固邦寧”). Based on this idea, Mencius developed the notion that people are the most important, the country comes second, and the king is the last (Ivanhoe 2007). Here, the concept of "people as the roots" is associated with the concept of the mandate of Heaven. Confucian philosophy postulates that Heaven's will, possibly understood as natural laws, governs this universe, in which the government is a subsystem and should follow its will (Dao 1996). By Confucian logic, because people are created by Heaven, and the people's will is the Heaven's will, thus, a government, to be legitimate, should exist for the benefits of the people. The mandate of Heaven also grants a virtuous ruler who treats his people well its protection and assistance, and thus, it can be even an authoritative means to overthrow tyranny and legitimize new rulers ( $\mathrm{Lu} 2000$ ).

Given that Confucianism was well embedded in the fabrics of Vietnamese society by the 10th century, it is understandable that, right from the beginning, the kings of the Ly dynasty (1010-1225) had long affirmed a narrative on the importance of the people to the nation and the kingship. In the spring of 1010, King Ly Thai To (974-1028) wrote the Capital Moving Proclamation (遷都詔) and issued it to move the capital of Dai Viet (the name of Vietnam at the time) from Hoa Lu (present-day northern province of Ninh Binh) to Dai La Citadel (Hanoi today). From the first lines of the Capital Moving Proclamation, the role of the people was mentioned as an essential requirement for this important work:

In the Shang Dynasty, Pangeng moved the capital five times, Cheng Wang of Chu Dynasty moved three times. The kings of three ancient dynasties (三代) did not to do their own will. They have done so in order to make great careers, as a strategy for their future generations. They obey the mandate of heaven and the people's will. They find a convenient place to move, so that the fate of the country becomes longer and customs increasingly prosperous (Le et al. 1993, 80-81). 
In this document, the king was shown to desire a long-term plan for the people to settle and become prosperous, making the empire prosperous as a whole (Le et al. 1993). The king had tied together the two concepts, "people's will" and "mandate of Heaven," marking a very Confucian idea. This dual linkage is reiterated many dynasties later. For example, under the Mac dynasty (15271529), King Mac Dang Dung (1483-1541) had declared: "Heaven chooses the king because of the people. The King obeys the mandate of Heaven in order to love the people," and "The people can row the boat but they also can make it sink" (Le et al. 1993, 80-81). Similarly, the famous poem "Close the harbour" by the Confucian scholar, poet and politician Nguyen Trai (13801442) echoes this thought:

The boat is overturned to know that people are like the water Based on the terrain is not difficult to compare with the sky Luck and misery come from the source, not just one day's work

Heroes leave their anger for thousands of years (Nguyen 1976, 201).

Popular in the Vietnamese history textbooks are the three miraculous victories against the Mongol army - which were believed to be due to the people's will. The military victory of Dai Viet was closely linked with the name of Tran Hung Dao (1228-1300). In 1288, shortly after winning the third time in the war against the Mongols, he told the royal family in the Tran dynasty (12251400) about the power of "the will of the people being the solid wall that protects the country." He summed up the cause of victory as a philosophy of democracy: "When the king and the people share one heart, the whole country is united." This is also his view concerning the national defense strategy that learning to use the strength of the people for the long-term survival is the best strategy of all (Le et al. 1993, 80). Here, once again the fate of the country is closely tied to the will of the people; as victory is thanks to the people's will while failure is blamed on the ruler's failure to gain the heart of the people. Another example is of Ho Quy Ly (1336-1407), a Vietnamese ruler who had carried out many important reforms but failed to unite the people against the Ming invasion. When both father and son were arrested by the Ming dynasty, Ho Nguyen Trung pointed out the cause of the failure: "I'm not afraid of fighting, I only fear that the people's heart/mind does not support me" (Le et al. 1993, 235).

The examples cited above have undoubtedly painted a harmonious picture of the relationship between the ruler and the ruled. Historians studying the Ly dynasty, however, suggest a less idealized approach, instead of adopting the conventional view that this dynasty had established a centralized state power in Vietnam in the 11th century (Taylor 1986). Although this view is not 
Tai-Dong Nguyen, Manh-Tung Ho, People as the Roots (of the State): Democratic Elements in the Politics of Traditional Vietnamese Confucianism

shared among scholars, it nonetheless provides a more factual look at the past, especially when reading into the king's writings. According to Taylor (1986), the Japanese researcher Yumio Sakurai even looked at the embankments built in Vietnam before and during the Ly dynasty and found that none served the agricultural purpose but they were either for military defense or anti-flooding purposes. Given that control over a unified agrarian system is often the basis of centralized dynastic power and such system is lacking in northern Vietnam, Sakurai concluded that the Ly dynasty was a "local dynasty" with direct control over only one of several regions in northern Vietnam (Taylor 1986). On this ground, Taylor (1986) went further and used the term "Ly dynasty religion" to emphasize that the Ly kings posed as men, not gods, but they did have superior moral qualities that aroused the supernatural powers dwelling in the Vietnamese realm - these powers were aroused to be protector spirits of the realm. As such, many practices at the time were seen by historians as a way the Ly kings used religious ideas to justify their authority. It is, thus, possible that the king's emphasis of the people's will in his declaration to move the capital in 1010 was a rhetorical move, even if his intentions were just as true (Lu 2000). Along this line, considering that state protection was at stake, one could also question how genuine Tran Hung Dao or Ho Quy Ly were when they stressed over and again their trust in the people's will. Vietnamese history books remain generous when describing its kings and heroes, which makes it difficult to inquire further on this matter.

\section{Loving the People}

If the will of the people and Heaven gives the monarch legitimacy, then their trust is the basis for political stabilization and national stability. This factor is repeated in various stories of Vietnamese kings, from Ly Thai To gaining power and bringing the dynasty to prosperity to Le Loi or later King Le Thai To (1385-1433) winning the war against the Ming and becoming a ruler. In order to win the trust of the people, the kings, acting as the role of parents, are advised to love the people. Confucius had emphasized that to be a human being is to have ren (仁) or benevolence, which is equivalent to loving humanity and the people. Thus, the act of loving the people must originate from one's moral character rather than as a political truce.

This idea is found throughout Vietnamese historical texts. King Tran Minh Tong (1300-1357), the fifth emperor of the Tran dynasty, told his trusted mandarin Tran Khac Chung (?-1330) about the reason why he led his soldiers to fight against the invaders: "I am the parents of the people. If the people 
meet difficult times, we must help them urgently" (Le et al. 1993, 238). Later, King Le Thanh Tong (1442-1497) also wrote:

I am a non-virtuous person who is the master of the people. I want everyone to be rich and happy for the country to prosper. Last year, from autumn to winter, it was not raining that people lost hope of crops and hunger. I am the parent of the people, but seeing that scene feels painful. If we do not practice grace throughout the country, how grace could not come to the people? (Le et al. 1993, 238).

Confucian scholars also interpret to love the people as to work for their happiness, which in turn also means to not be selfish and instead be sympathetic to the will of the people (Bui 2013, Ta 2009). On this note, King Minh Mang (1791-1841), the second emperor of the Nguyen dynasty (18021945), had once said in a nationwide royal proclamation that: "The kingly way is to consider peace the criterion and to accumulate five happinesses ${ }^{1}$ for the people" (Bui 2013). In addition, loving the people is the duty of the king as much as of the mandarins. In 1434, Le Thai Tong (1423-1442) ordered the mandarins as follows: "The mandarins have two important things. One is loving the king, the other is loving the people" (Le et al. 1993, 373).

Similar to the rhetoric about listening to the will of the people, the need to win the trust and love of the people is crucial to ensuring the image of a virtuous ruler as much as a successful kingship and stable empire. Steeped in Confucian teaching, feudal Vietnamese rulers were no exception to this traditional moral norm.

\section{Ensuring Peace for the People}

Another important criterion for evaluating a king is to see whether he fulfills the purpose of ensuring peace for the people - the concept of 'yên dân' (安 民). This action means that under a king's reign, the people could enjoy food, warmth, peace, and stability and be peaceful; the people were free from anxiety and could grow personally and fulfill their obligations to the community and society. For example, when assessing King Ly Thai To's character at an early age, the monk Van Hanh said: "This is an extraordinary person. Later on, when this person grows up, he will be able to help the country, ensure peace for the people, and be the lord of the people" (Le et al. 1993, 34). Historians also use the interests of the people as a criterion for assessing a king's career. An example of this is found in an excerpt about the third emperor of the Ly dynasty King Ly Thanh Tong (1023-1072): "The king truly loves the people,

1 The term "five happinesses" refers to the ninth division of "the Great Plan" in the Book of History, which consists of long life, riches, soundness of body and serenity of mind, the love of virtue, and an end crowning the life. 
Tai-Dong Nguyen, Manh-Tung Ho, People as the Roots (of the State): Democratic Elements in the Politics of Traditional Vietnamese Confucianism

helps develop agriculture, governing the country makes people live in peace, thus deserving to be called the good king. However, his mistake was wasting the strength of the people to build the tower Bao Thien, waste of people's wealth to make the palace Dam Dam" (Le et al. 1993, 105).

In the Tran dynasty, which followed from the Ly dynasty, the view of ensuring the strength of the people by Tran Hung Dao became a strategy to build and maintain the country. This view is reflected in the conversation between the fourth emperor of the Tran dynasty Tran Anh Tong and Tran Hung Dao about the threat of invasion from the north:

"In the Dinh and Le dynasties, the king knew how to use the talented people so that the southern area (Vietnam) stayed strong while the northern area (China) became weak. The people of the whole country should build Binh Lo citadel that will beat the Song dynasty. If only to see the enemy to run like fire, as the wind is easy to control. If they are moving as slow as silkworms are eating, then we have to use generous generals, calculated like chess at the same time build a heart as father and son to win. Ensuring the strength of the people as a long-term plan, that is the best strategy to hold the country" (Le et al. 1993, 210211).

The concept of ensuring peace for the people continued to thrive in the writings of the Confucian scholar Nguyen Trai, who served under the reign of King Le Thai To from 1428 to 1433. In the first lines of the Great proclamation upon the pacification of the $W u$, he wrote: "To ensure peace for the people, such is the essence of humanity and justice. To eliminate violence, such is the primary aim of our soldiers" (Le et al. 1993, 354). Similarly, when the first doctoral candidate Giap Hai (1515?-1585?), the minister of interior under the Mac dynasty, realized that the policy of the Mac did not come from the interests of the people, he said:

It is because of man that Heaven caused disaster. Natural disaster is the warning of heaven. I look forward to the king when he sees the calamity of the sky, then feel fear, then modify the politics... enforce the policy of grace for the oppressed innocent; in particular, order local officials to visit and help them. If such work is done then the king's favor comes to the people. When the people feel happy, the calamity of heaven will cease... Please respect the roots of the country, unify the people's hearts, treat people kindly instead of making their life difficult; helping the people instead of harming..., that means the king's way (Phan 1992, 256-257).

In the will the great mandarin Mac Ngoc Lien (?-1594) left to advise the 10th emperor of the Mac dynasty Mac Kinh Cung (?-1625), this point is also 
stressed, invoking the mandate of Heaven in his call for restraint from the use of force:

Now the Mac dynasty was over then the Le dynasty restored, that is the heaven's will. Innocent people have suffered from war. We should avoid being in another country, nurturing our strengths and waiting to see when the fate of heaven comes back to us. We should not use force. Two tigers are fighting, and one is injured. If they see their army, we should avoid, do not fight, so be careful to keep more. We should not invite the Ming into our country but let our people live in misery, it is also a great $\sin$ (Le et al. 1993, 642-643).

Making sure that the life of the people is good and prosperous, therefore, is the purpose of ruling the country. In this Confucian teaching, politics is to bring good things to the people. If the head of the centralized power system and the bureaucracy treats the people as the purpose, then this purpose is fulfilled. If the people's life is not peaceful, then the people will lose faith, which will pose political threats to the existing monarchy. As this paper previously pointed out, the highest democratic expression of the peasants is often believed to be their violence against tyranny - by overthrowing the tyrant and corrupt officials, the people move toward their dream of a just society with a sage king and good mandarins (Phan 1998). This idea can also be found in folk proverbs such as "winner is king, loser is the enemy," or "Whence the people make the revolution, the Son of the King sweep the temple." In The importance of Sanitation, the great Vietnamese thinker and famous physician Le Huu Trac (1720-1791) wrote: "It is better to incite violence than to starve in the street" (Phan 1998, Phan 1992). Thus, these interpretations suggest that the idea of democracy among Vietnamese peasants is limited to their demand for social stability, which can pose a threat to the ruling power if not met. This has a legitimate and positive presence in the struggle against tyranny and the injustice of feudal society, yet it also reveals the powerless nature of peasants in their personal liberation (Nguyen 2004a, b).

In this respect, traditional Vietnamese politics only tend toward order rather than liberty. It is true that order and freedom are sometimes in harmony and sometimes they contradict each other. In Confucian ideology is used primarily for the purpose of social stability and the stability and security of the country. The order of society is placed above personal freedom. In other words, the people's will has a stronger implication for the destiny of the nation at large rather than for individual freedom. By abiding the will of the people through loving and ensuring peace for them, which is also the mandate of Heaven, the monarch fulfills his moral duty and ensures his own successful leadership. 
Tai-Dong Nguyen, Manh-Tung Ho, People as the Roots (of the State): Democratic Elements in the Politics of Traditional Vietnamese Confucianism

\section{The Concept of People as the Roots and its Implications for Building a Modern Democracy}

In an in-depth analysis of classical Chinese rhetoric and its influence on contemporary Chinese political communication, $\mathrm{Lu}$ (2000) noted how despite the myriads of changes in Chinese society over the centuries, the rhetorical forms and themes, such as an emphasis on moral idealism and legitimation of power, remain fundamentally the same. Examining the historical Vietnamese texts points to a similar trend-that feudal rulers who are well versed in Confucianism and other classical texts have regularly used Confucian rhetoric to express their care for the people, and in turn, legitimizing their leadership. Yet, at the same time, it is undeniable that there is a progressive element in the idea that the people's interests should be first and foremost under a monarchy or even throughout the feudal period. This paper argues that this progressiveness - particularly the concept of "people as the roots" is a manifestation of village democracy in the context of feudal Vietnam. Given that material prosperity is a critical precondition of democracy, even if this Confucian concept is not analogous to democracy itself, some of its features could facilitate the growth of an inclusive and empowered regime (Murthy 2000).

\section{Village democracy}

The social structure of Vietnamese village societies plays an important role in maintaining democratic elements in the countryside as well as connecting the people against the arbitrary, tyrannical order of the monarch. Rural democracy (or village democracy) is the driving force for unity in villages and communes, and to limit conflicts among the people. Traditionally, democracy in the commune is based on the participation of three informal social groups. They have no backing from mandatory and official institutions but rely on credibility, compromise, and power of the public opinion instead of the power of the law. The three informal groups are: Lão, Hào, Mục. The Lão group is an elderly group that has taken age and experience as the foundation for their credibility. The Hào are retired officials who have a role in the village or hold senior positions outside of the village. This group relies on individual influences and voices to balance the "weight of the voices" toward the work of a village. The Muc group usually includes those who are highly educated, successful, and have official qualifications. They use their broad knowledge to have stronger voices in the general work of a village (Mai, Nguyen, and Nguyen 2011, Vu, Do, and Pham 2004, 65). The informal groups act as the mediators for different interests within a community or a village. 
Whereas in the West, the subject and the center of the theory of democracy is always the individual, in Vietnamese history, there can be no real democracy if the individual does not place himself in a collective village. Equality and democracy among members are recognized when they are village members (Nguyen 2004a, b). Although in Confucian thought there are many factors related to inner freedom, these factors refer to the spiritual quality that must be cultivated by each person. This kind of freedom is often constrained by political regimes, which do not promote the rights and interests of the individual as a member of the community (Phan 1998).

Village democracy is truly democratic only when it is placed in a political system where the rights of an individual are protected under the law, not just because of his or her membership of a group. Therefore, there is no going straight from traditional village democracy to modern democracy. Yet, village democracy can still be a driving force toward a true democracy because it allows for the unity among the villagers and limits of internal conflicts. Traditionally, village democracy is based on the three informal mechanisms in each village whereby the informal groups are important actors: prestige, compromise, and the power of public opinion rather than the power under a law (Vu, Do, and Pham 2004).

\section{From Village Democracy to Modern Democracy}

In Confucian political culture, there is no direct transition from the will of the people to political power. Because the traditional Confucian political conception is a combination of the power of the monarch vested in him by the Heaven and the power of the mandarins (mainly through imperial examinations). The division of power does not seem to be established in the monarchy. The kings are afraid of and thoroughly prevent factionalism or sectarianism (Le et al. 1993) as they are considered disorder, usurpation, and unforgivable crimes.

Confucianism became the dominant ideology in order to maintain the king's power and the bureaucratic system. As such, the expression and execution of the will of the people also aimed at achieving that goal. The importance of the people (people as the roots, the people is the most important) is fundamentally different from the concept of "power belonging to the people" of democratic politics today. It should be reiterated that the notion of "punishment not applied on high-ranking mandarin, the ritual not applied to the people" (Vu, Do, and Pham 2004) is a common concept in political regimes in China as well as in Vietnam. When distinguishing between the concept of "people as 
Tai-Dong Nguyen, Manh-Tung Ho, People as the Roots (of the State): Democratic Elements in the Politics of Traditional Vietnamese Confucianism

the roots" in Confucianism and that of democracy, the Chinese scholar and reformist Liang Qichao (1873-1929) wrote:

In the United States, when talking about politics, Lincoln put forward three prepositions to cover all: of the people, by the people, and of the people... The Chinese doctrine speaks of 'for', but the meaning of 'by' does not seem to be heard... What do civil unions do without political power? The biggest disadvantage of Chinese political theory is here (Liang (1996) as cited in (Ly 2006)).

The Confucian concept clearly implies that the will of the people is not institutionalized and the people do not have the rights to participate in official affairs.

This is not to say that village democracy has no value. It remains a force, its power is not based on human liberation and respect for human rights, but through tying people in community relations and ensures equal human rights as community members. For people living under feudalism, village democracy then was only about the active fulfillment of their obligations, the worshiping of the ancestors, or the bonds among people of the same roots sharing the same blood. In contrast, a civil society is a society built on the basis of equality between the state and the citizens, and among citizens on the basis of law. To develop a civil society starting from a village society, it is necessary to address the underlying contradictions and implement a number of specific solutions such as ensuring the dynamism and self-motivation for each citizen (Nguyen 2004a, b). This is important for the modern nationbuilding process, which carries more than mere policy implementation and institution establishment, it also concerns the creation of a unified national identity in the face of ethnic diversity and cultural fragmentation (Derichs and Heberer 2006).

Despite all the inherent defects, village democracy has also nurtured some form of self-management. The French author of La commune annamite au Tonkin, Paul Ory (1894), once reminded colonial rulers that: "The village of Vietnam governs itself. The state should not interfere in the work of the village unless the village does not fulfill its obligation to pay poll-tax, landtax, serve as coolie and go into the army" (Tuong 2007).

Given the absence of independent individuals or the citizen element, the constrained version of village democracy is hard to put in practice in today's democracy. This explains why many reforms, such as those of the Vietnamese reformer Nguyen Truong To (1830-1871), have failed. When one puts all the trust in the dynasty instead of the people, Vietnamese history teaches that such endeavors are bound to doom. 
"Nguyen Truong To only told the king and mandarins, but it is clearly not enough. If the whole of Vietnam became more intelligent and more aware of their time, then maybe his efforts were more likely to succeed. This requires a long process, beginning with helping people in the society understand the nature of what is happening, thereby changing the way they think, and thereby influencing how they behave. Many people in the same positive change will create a better society" (Tia Sang 2010).

\section{Conclusion}

Through the historical examples of how highly Vietnamese feudal rulers value the people's will, loving the people and ensuring peace for the people, the paper has explored the concept of "people as the roots" (of the state). These examples show that these Confucianism-imbued democratic elements have always been present in traditional Vietnamese society.

Nonetheless, it is important to note that these elements had not amounted to the modern sense of democracy, in the sense that the individual's interests and rights are institutionalized and protected under the law. They should only be understood as the constituents of a village democracy, where there is no official institution or law and the power structure is balanced through informal means: social prestige, public opinion, and compromise. This distinction suggests an implication for the process of democratization of modern Vietnamese society: the concept of "people as the roots," as democratic as it can be, does not necessarily translate directly to a modern democracy, although it has been essential for a village democracy and might be very valuable for building a democracy. Here, to help the transition from a village democracy to a modern democracy become smoother, the development of a strong civil society could offer a solution. To develop a civil society starting from a village society, one should ensure the dynamism and self-motivation for each citizen (Nguyen 2004a, b) as well as a unified national identity (Derichs and Heberer 2006). The process will be complex, but such is the price for a modern democracy.

Along this note, future studies could expand the scope to analyze the connection between "grassroots democracy" and the concept "people as the roots," given that village elections and local governance are increasingly being held accountable (Wang and Yao 2007, Stout 2010, Abers 2000). Studies on the implementation of grassroots democracy in rural areas in Vietnam have found some evidence that Vietnamese political reforms over the years have allowed greater space for collective action (Wells-Dang 2010, Larsen 2011, Fritzen 2006). However, they also point out the important role of the central government to provide resources and institutional frameworks so that 
Tai-Dong Nguyen, Manh-Tung Ho, People as the Roots (of the State): Democratic Elements in the Politics of Traditional Vietnamese Confucianism

the grassroots democracy initiative can be more effective in improving good governance. It is then arguable that this discussion can be enriched with the concept "people as the roots," a concept well grounded in the Confucian heritage and Vietnamese history. With this advantage, the concept "people as the roots" can also be suitable for future studies on grassroots democracy in societies where Confucianism has a dominant presence. More importantly, future studies can also explore the link between taking "people as the roots" of the state and the process of nation-building. Future scientific research in these directions is important for the democratic elements to take deeper roots in these societies and for nation-building to succeed, which will serve the people and justify the cost of doing science (Vuong 2018).

\section{Acknowledgment}

This research is funded by the Committee of Ethnic Minority Affairs according to the national grant No. CTDT.24.17/16-20. The authors would like to thank Prof. Michal Valco, Prof. Ho Si Quy and Dr. Tran Tuan Phong for their continued support and advice throughout this study. The authors would like to thank their colleagues at the Institute of Philosophy, Vietnam Academy of Social Sciences for their assistance during the research process. The authors would like to express the highest gratitude for Mrs. Nguyen To Hong Kong for providing excellent support during the editing and proofreading process.

\section{References}

Abers, Rebecca. 2000. Inventing local democracy: grassroots politics in Brazil: Lynne Rienner Publishers.

Ackerly, Brooke A. 2005. "Is liberalism the only way toward democracy?" Political Theory 33 (4):547-576. doi: 10.1177/0090591705276879.

Bell, Daniel A. 2009. "Reconciling socialism and Confucianism?: Reviving tradition in China." Dissent 57 (1):91-99. doi: 10.1353/dss.0.0114.

Bui, Ngoc Son. 2013. “Confucian Constitutionalism in Imperial Vietnam.” National Taiwan University Law Review 8 (2):373-435.

Chang, Y., Y. Chu, and F. Tsai. 2005. "Confucianism and democratic values in three Chinese societies.” Issues \& Studies 41 (4):1-33.

Chen, Albert H. Y. 2007. "Is Confucianism compatible with liberal constitutional democracy?” Journal of Chinese Philosophy 34 (2):195-216. doi: 10.1111/j.1540-6253.2007.00409.x.

Dao, Minh Chau. 1996. "Administrative concepts in confucianism and their influence on development in Confucian countries." Asian Journal of Public Administration 18 (1):45-69. doi: 10.1080/02598272.1996.10800317. 


\section{Journal of Nationalism, Memory \& Language Politics 13(1)}

Derichs, Claudia, and Thomas Heberer. 2006. "Introduction: Diversity of Nation-building in East and Southeast Asia." European Journal of East Asian Studies 5 (1):1-13. doi: 10.1163/157006106777998061.

Dirlik, Arif. 1995. "Confucius in the borderlands: Global capitalism and the reinvention of Confucianism." boundary 222 (3):229-273. doi: 10.2307/303728.

Duong, Minh Nhut. 2004. “Grassroots democracy in Vietnamese communes.” [Research Paper]. Centre for Democratic Institutions, Research School of Social Sciences, Australian National University, accessed May 25. http://archives.cap.anu.edu.au/cdi_anu_edu_au/ CDIwebsite_1998-2004/vietnam/veitnam_downloads/Doung_Grassrootsdemocracypaper.pdf.

Fritzen, Scott A. 2006. "Probing system limits: Decentralisation and local political accountability in Vietnam." Asia Pacific Journal of Public Administration 28 (1):1-23.

Fröhlich, Thomas. 2010. "'Confucian democracy” and its Confucian critics: Mou Zongsan and Tang Junyi on the limits of Confucianism." Oriens Extremus 49:167-200.

Fukuyama, Francis. 1995. "Confucianism and Democracy." Journal of Democracy 6 (2):20-33. doi: 10.1353/jod.1995.0029.

Ho, Si Quy. 2015. "Di sản truyền thống: Dân chủ hay thiếu dân chủ [Traditional heritage: democratic or undemocratic]." Tạp chi Thông tin Khoa học Xã hội (3):3-11.

$\mathrm{Hu}$, Shaohua. 1997. "Confucianism and Western democracy." Journal of Contemporary China 6 (15):347-363. doi: 10.1080/10670569708724282.

Huntington, Samuel P. 1991a. “Democracy's Third Wave.” Journal of Democracy 2 (2):12-34. doi: 10.1353/jod.1991.0016.

Huntington, Samuel P. 1991b. The Third Wave: Democratization in the Late Twentieth Century (Vol. 4). Norman: University of Oklahoma Press.

Ivanhoe, Philip J. 2007. "Heaven as a Source for Ethical Warrant in Early Confucianism." Dao 6 (3):211-220. doi: 10.1007/s11712-007-9013-1.

Kim, Sungmoon. 2017. "Pragmatic Confucian democracy: rethinking the value of democracy in East Asia." The Journal of Politics 79 (1):237-249. doi: 10.1086/687762.

King, Ambrose, ed. 1996. The Transformation of Confucianism in the Post-Confucian Era: The Emergence of Rationalistic Traditionalism in Hong Kong. Edited by Tu Wei-ming, Confucian Traditions in East Asian Modernity. Cambridge, MA: Harvard University Press.

Larsen, Rasmus Klocker. 2011. "Reinventing rural development in Vietnam: Discursive constructions of grassroots democracy during the renovation reform." Asia Pacific Viewpoint 52 (3):316-332.

Le, V. H., Phan P. H., S.L. Ngo, Q. Vu, C.T. Pham, and H. Le. 1993. Dai Viet Su Ky Toan Thu [Dai Viet History]. Hanoi: Social Science Publishing House.

Lee, Teng-hui. 1999. "Confucian democracy: Modernization, culture, and the state in East Asia." Harvard International Review 21 (4):16-18.

Liang, Qichao. 1996. Qi political ideology. China: Eastern Publishing House.

Lu, Xing. 2000. "The influence of classical Chinese rhetoric on contemporary Chinese political." Chinese Perspectives in Rhetoric and Communication (1):1. 
Tai-Dong Nguyen, Manh-Tung Ho, People as the Roots (of the State): Democratic Elements in the Politics of Traditional Vietnamese Confucianism

Ly, T. S. 2006. "The purpose of the population of the democracy." Vietnamese Journal of Journalists 12 .

Mai, T. K. T, T. T. Nguyen, and T. Nguyen. 2011. "Vai trò của định chế xã hội trong việc phát huy dân chủ ở nông thôn Việt Nam hiện nay dưới góc nhìn công tác xã hội [The Role of Social Institutions in Promoting Democracy in Rural Vietnam from a Social Work Viewpoint]." Vietnamese Journal of Sociology 3 (115):107-117.

Murthy, Viren. 2000. “The Democratic Potential of Confucian Minben Thought.” Asian Philosophy 10 (1):33-47. doi: 10.1080/09552360050001752.

Nguyen, Minh Tuan. 2004a. "Dân chủ trong chế độ phong kiến Việt Nam [Democracy in Feudalism in Vietnam].” Vietnamese Journal of Legislative Studies 10 (45):62-67.

Nguyen, Minh Tuan. 2004b. "Làng xã xưa và nay [Village: ancient and present]." Vietnamese Journal of Science and Homeland 11-12.

Nguyen, T. 1976. Toan tap [Collected Works]. Hanoi: Social Science Publishing House.

Nuyen, A. T. 2000. "Confucianism, the Idea of Min-Pen, and the Democracy." The Copenhagen Journal of Asian Studies 14 (1):130. doi: 10.22439/cjas.v14i1.2154.

Ory, P. 1894. La commune annamite au Tonkin [The Annamite commune at Tonkin]. Paris: Augustin Challamel.

Phan, H. C. 1992. Lịch triều hiến chuong loại chi [Annals of the Laws and Institutions of Successive Dynasties]. Vol. 1. Hanoi: Social Science Publishing House.

Phan, Huy Le. 1998. "Vấn đề dân chủ trong truyền thống Việt Nam [The Problem of Democracy in the Vietnamese Tradition]." Journal of Homeland (4).

Shi, Tianjian, and Jie Lu. 2010. “The Shadow of Confucianism.” Journal of Democracy 21 (4):123-130. doi: 10.1353/jod.2010.0012.

Stout, Jeffrey. 2010. Blessed are the organized: Grassroots democracy in America: Princeton University Press.

Ta, V. T. 2009. "Confucian Influences in the Traditional Legal System of Vietnam, with Some Comparisons with China: Rule by Law and Rule of Law." Vietnamese Social Science Review 11:11-34.

Tan, Sor-hoon. 2010. "Confucianism and Democracy." In Confucianism in Context- Classic Philosophy and Contemporary Issues, East Asia and Beyond, edited by W. Chang and L. Kalmanson, 103-120. New York: SUNY Press.

Taylor, Keith W. 1986. "Authority and Legitimacy in 11th century Vietnam." In Southeast Asia in the 9th to 14th Centuries, edited by David G. Marr and Anthony Crothers Milner, 139-176. Singapore: Institute for Southeast Asian Studies.

Tia Sang. 2010. "Từ Fukuzawa Yukichi nhìn về Nguyễn Trường Tộ [From Fukuzawa Yukichi looking at Nguyen Truong To].” Tia Sang,, accessed Feb 06. http://tiasang.com.vn/dien-dan/tu-fukuzawa-yukichi-nhin-ve-nguyen-truong-to-3232.

Tu, Weiming. 1984. Confucian Ethics Today: The Singapore Challenge: Federal Publications.

Tuong, L. 2007. "Xã hội dân sự và mấy vấn đề của các tổ chức xã hội [Civil Society and the Problems of Social Organizations].” Vietnamese Journal of Legal Science 4 (41). 
Vu, T. K., T. T. Do, and B. H. Pham, eds. 2004. Phát triển nông thôn Việt Nam tù làng xã truyền thống dến văn minh thời đại [Rural development in Vietnam from traditional village to the civilization era]. Hanoi: Agriculture Publishing House.

Vuong, Quan Hoang, and Tri Dung Tran. 2009. "The cultural dimensions of the Vietnamese private entrepreneurship." IUP Journal of Entrepreneurship Development VI (3-4):54-78.

Vuong, Quan Hoang. 2014. "Vietnam's political economy: a discussion on the 1986-2016 period." WP-CEB $N^{\circ} 14-010$ Universite Libre de Bruxelles.

Vuong, Quan Hoang. 2016. "Impacts of geographical locations and sociocultural traits on the Vietnamese entrepreneurship." SpringerPlus 5 (1):1189.

Vuong, Quan Hoang. 2018. The (ir)rational consideration of the cost of science in transition economies. Nature Human Behaviour 2(1): 5. doi: https://doi.org/10.1038/s41562-0170281-4

Vuong, Quan Hoang. 2019. “The financial economy of Viet Nam in an age of reform, 19862016." In Routledge Handbook of Banking and Finance in Asia, edited by U Volz, P Morgan and N Yoshino, 201-222. London, UK: Routledge (T\&F).

Vuong, Quan-Hoang, Quang-Khiem Bui, Viet-Phuong La, Thu-Trang Vuong, Viet-Ha T. Nguyen, Manh-Toan Ho, Hong-Kong T. Nguyen, and Manh-Tung Ho. 2018. "Cultural additivity: behavioural insights from the interaction of Confucianism, Buddhism and Taoism in folktales." Palgrave Communications 4 (1). doi: 10.1057/s41599-018-0189-2.

Wang, Shuna, and Yang Yao. 2007. "Grassroots Democracy and Local Governance: Evidence from Rural China.” World Development 35 (10):1635-1649. doi: https://doi.org/10.1016/j. worlddev.2006.10.014.

Weller, Robert P. 1999. Alternate Civilities. Boulder, CO: Westview Press.

Wells-Dang, Andrew. 2010. "Political space in Vietnam: a view from the 'rice-roots'. The Pacific Review 23 (1):93-112. doi: 10.1080/09512740903398355.

Zingerli, Claudia. 2004. "Politics in mountain communes: Exploring Vietnamese grassroots democracy." In Rethinking Vietnam, edited by Duncan McCargo, 69-82. London: Routledge. 